\title{
KEMAMPUAN BERPIKIR KRITIS SISWA DALAM MEMECAHKAN MASALAH MATEMATIKA
}

\author{
Pradina Parameswari ${ }^{1}$, Thoufina Kurniyati ${ }^{2}$ \\ ${ }^{1}$ Alumni Magister Pendidikan Matematika, Universitas Negeri Malang, ${ }^{2}$ SMA Modern Al-Rifa'ie Malang \\ Email: ${ }^{1}$ pradinamtk@gmail.com, ${ }^{2}$ thoufinakurniyati@yahoo.co.id
}

\begin{abstract}
ABSTRAK
Salah satu kompetensi penting yang dibutuhkan siswa dalam menghadapi perkembangan pendidikan di abad ke-21 adalah kemampuan berpikir kritis. Dengan memiliki kemampuan ini, siswa dapat menyelesaikan berbagai masalah dalam kehidupan sehari-hari menggunakan pemikiran yang rasional dan kritis. Menindaklanjuti hal tersebut maka perlu melakukan penelitian untuk mengukur kemampuan berpikir kritis siswa. Oleh karena itu, penelitian ini bertujuan untuk menganalisis kemampuan berpikir kritis siswa melalui pemberian masalah matematika. Penelitian ini merupakan penelitian kualitatif-deskriptif. Instrumen penelitian berupa satu masalah matematika pada materi geometri dan wawancara. Masalah matematika ini diberikan kepada 23 siswa kelas X MIPA 2. Hasil pekerjaan siswa dianalisis menggunakan indikator kemampuan berpikir kritis yang ditetapkan oleh peneliti, antara lain: interpretasi, analisis, evaluasi, dan inferensi. Dari hasil analisis tersebut diperoleh bahwa: (a) siswa yang memenuhi indikator interpretasi sebanyak $86,9 \%$ (20 siswa dapat melakukan interpretasi dengan baik), (b) siswa yang memenuhi indikator analisis sebanyak 47,8\% (11 siswa dapat melakukan analisis dengan baik), dan (c) siswa yang memenuhi indikator evaluasi dan inferensi sebanyak $0 \%$ atau tidak ada siswa yang memenuhi indikator evaluasi dan inferensi. Berdasarkan hasil penelitian dapat disimpulkan bahwa kemampuan berpikir kritis siswa masih rendah yang terlihat pada belum tercapainya indikator analisis, evaluasi, dan inferensi dengan baik.
\end{abstract}

Kata Kunci: Berpikir Kritis, Pemecahan Masalah, Masalah Matematika,

\begin{abstract}
One of the important competencies which needed by students in facing the development of education in the 21st century is critical thinking skill. By having this skill, students can solve various contextual problems using rational and critical thinking. To respond that statment, it is necessary to make research to measure students' critical thinking skills. Therefore, this study aims to analyze students' critical thinking skills through practice mathematical problems. This study is a qualitative-descriptive research. The instruments is a mathematical problem especially geometry and interviews. This mathematical problem was given to 23 students of Class X MIPA 2. The results of students' work sheet were analyzed using indicators of critical thinking skills set by the researchers, including: interpretation, analysis, evaluation, and inference. From the results of the analysis it was found that: (a) students who satisfy the interpretation indicator were $86.9 \%$ (20 students were able to interpret it well), (b) students who satisfy the analysis indicators were 47.8\% (11 students could do the analysis by well), and (c) students who satisfy the evaluation and inference indicators are $0 \%$ or none of the students satisfy the evaluation and inference indicators. Based on the results of the study it can be concluded that students' critical thinking skill is still low as seen in not yet reached indicators of analysis, evaluation, and inference by well.
\end{abstract}




\section{PENDAHULUAN}

Perubahan zaman yang memasuki abad ke-21 menuntut setiap individu untuk memiliki keterampilan dan kemampuan yang relevan dengan perkembangan era revolusi industri 4.0 (Widana, dkk., 2019). Keterampilan tersebut dikenal dengan istilah 4Cs, meliputi critical thinking, creative thinking, collaboration, dan communication skill (Widana, dkk., 2019 \& As'ari, 2016). Critical thinking merupakan keterampilan yang harus dimiliki setiap individu khususnya siswa yang sesuai dengan Permendikbud nomor 20 tahun 2016. Hal ini dikarenakan kemampuan berpikir kritis sangat penting bagi siswa dalam menghadapi masalah atau situasi yang sulit dan menuntut mereka untuk mengambil keputusan yang rasional dan kritis (Basri, dkk., 2019; Filah, 2018; dan As'ari, dkk., 2017).

Berpikir kritis merupakan proses berpikir yang reflektif, masuk akal, dan sistematis dalam menganalisis informasi atau masalah untuk menentukan keputusan yang valid (Syarifah, dkk., 2018; Duron, dkk., 2006). Definisi tersebut sejalan dengan pernyataan Ennis (2011) bahwa berpikir kritis sebagai berpikir yang menitikberatkan pada penarikan keputusan yang akan dipercayai atau dilakukan secara logis dan reflektif. Di sisi lain Facione (2018) mendeskripsikan berpikir kritis sebagai berpikir yang bertujuan untuk membuktikan, menjelaskan, dan menjabarkan maksud suatu pernyataan atau informasi dan menyelesaikan suatu masalah tertentu. Lebih lanjut Felder, R. M., \& Brent, R., (2016:231) menambahkan bahwa dengan memiliki kemampuan berpikir kritis, seseorang dapat membuat penilaian dan keputusan berdasarkan bukti yang valid dan masuk akal (logic). Oleh sebab itu, seseorang yang dapat berpikir kritis dengan baik dapat memilah informasi yang diperoleh untuk diuji kebenarannya sehingga tidak mudah tertipu.

Kemampuan berpikir kritis dapat dilatih, salah satunya melalui pendidikan atau pembelajaran (Syarifah, dkk., 2018; Hidayanti, dkk., 2016; Firdaus, dkk., 2015). Hal ini dikarenakan berpikir kritis tidak secara alami diperoleh setiap individu (Cahyono, 2017). Oleh sebab itu, peran tenaga pendidik sangat penting untuk membantu siswa menjadi pemikir kritis yang baik (Felder, R. M., \& Brent, R., 2016:230). Salah satu pelajaran yang membutuhkan pemahaman yang mendalam akan suatu konsep serta membutuhkan kemampuan berpikir kritis untuk menyelesaikan masalah adalah matematika (As'ari, dkk., 2017). Pernyataan tersebut juga didukung oleh Chukwuyenum (2013) bahwa kemampuan berpikir kritis perlu ditekankan dan diintegrasikan pada pembelajaran matematika di sekolah. Dengan demikian siswa dapat menggunakan keterampilan berpikir kritis dengan baik untuk memecahkan masalah matematika maupun dalam kehidupan sehari-hari.

Pentingnya peranan berpikir kritis dalam pembelajaran matematika menjadi pusat perhatian. Oleh sebab itu, setiap sekolah harus dipastikan setiap siswanya telah memiliki keterampilan tersebut. Namun kenyataan di lapangan tidak demikian. Sebagian besar kemampuan berpikir kritis siswa masih cenderung rendah. Peneliti melakukan observasi terhadap tiga siswa kelas X MIPA di salah satu SMA swasta Kab. Malang. Tiga siswa tersebut dipilih secara acak. Berikut soal observasi tersebut.

Jika fungsi $f$ didefinisikan $f(x)=x+2$ dan $f: A \rightarrow B$ dimana $A:\{1,2,3\}$ dan $B:\{x \mid x \leq 5, x \in$ Bil. Asli $\}$, maka tentukan $f^{-1}$.

Gambar 1. Soal Observasi

Hasil dari observasi tersebut menunjukkan bahwa ketiga siswa belum dapat menggunakan kemampuan berpikir kritis dengan baik. Hal ini dapat dilihat dari hasil pekerjaan mereka. Berikut hasil pekerjaan siswa $\mathrm{P}$, siswa Q, dan siswa R.

\begin{tabular}{|c|c|c|}
\hline Dikn $f(x)=x+2$ & & $f(x)=x+2$ \\
\hline$f: A-B$ dimana & $1 \div 2+2$ & $F(x)=u$ \\
\hline $\begin{array}{l}A=\{1,0,3\} \text { dan } \\
B,\{x \mid x \leq 5, x \in 0,1, A \text { si }\end{array}$ & $\frac{4}{7} x+2$ & $y=x+2$ \\
\hline B. $\{1,2,3,4,54$ & $x+7=y$ & $y-2=x$ \\
\hline maicat $f(x)=y$ & $x+y=2$ & $-2 y=x$ \\
\hline $\begin{array}{l}y=x+2 \\
x=y-2\end{array}$ & $f^{-1}=2-2$ & $x=-2 y$ \\
\hline$t^{-1}=x-2$ & & $x=-3 x$ \\
\hline Siswa $\mathbf{P}$ & Siswa $\mathbf{Q}$ & Siswa $\mathbf{R}$ \\
\hline
\end{tabular}

Gambar 2. Hasil Pekerjaan Siswa P, Siswa Q, dan Siswa R 
Pada Gambar 2, siswa P mampu menyelesaikan masalah dengan langkah awal mengidentifikasi setiap anggota himpunan A sebagai daerah asal (domain) dan anggota himpunan B sebagai daerah kawan (kodomain). Kemudian siswa $\mathrm{P}$ menentukan invers dari fungsi $f$ dengan membuat permisalan $f(x)=y$ sedemikian sehingga diperoleh $x=y-2$ atau $f^{-1}(x)=x-2$. Hal yang sama dengan siswa $\mathrm{Q}$ dengan tahapan pengerjaan yang sama diperoleh nilai $f^{-1}(x)=x-2$. Namun, baik siswa $\mathrm{P}$ dan siswa Q tidak melakukan evaluasi dengan mengecek apakah $f^{-1}$ merupakan suatu fungsi. Sedangkan untuk siswa $\mathrm{R}$ tidak dapat menentukan nilai atau menemukan $f^{-1}$ karena kesalahan dalam melakukan prosedur perhitungan. Dengan demikian dapat disimpulkan bahwa siswa masih belum dapat mengunakan kemampuan berpikir kritis dengan baik. Untuk menindaklanjuti hal tersebut, peneliti merasa perlu melakukan penelitian terkait proses berpikir kritis siswa dalam memecahkan masalah.

Untuk mengukur kemampuan berpikir kritis diperlukan beberapa indikator. Menurut Ennis (1985), terdapat beberapa indikator kemampuan berpikir kritis, antara lain: (1) memberikan penjelasan sederhana, yaitu keterampilan memfokuskan pertanyaan, menganalisis argumen, bertanya dan menjawab pertanyaan, (2) membangun keterampilan dasar, yaitu menyesuaikan dengan sumber, mengamati dan melaporkan hasil observasi, (3) menyimpulkan, yaitu keterampilan mempertimbangkan kesimpulan, melakukan generalisasi dan melakukan evaluasi, (4) membuat penjelasan lanjut seperti mengartikan istilah dan membuat definisi, dan (5) mengatur strategi dan taktik seperti menentukan suatu tindakan, berinteraksi dengan orang lain, dan berkomunikasi. Pendapat lainnya juga dikemukakan oleh Facione (2018) yaitu ada enam komponen berpikir kritis, antara lain interpretation, analysis, evaluation, inference, explanation, dan self-regulation. Sedangkan Chukwuyenum (2013) menyatakan berpikir kritis terdiri atas kegiatan mengumpulkan, menginterpretasikan, menganalisis, dan mengevaluasi informasi untuk mendapatkan kesimpulan yang valid dan dapat dipercaya.

Pada penelitian ini peneliti menetapkan indikator berpikir kritis berdasarkan pendapat Facionne (2018). Namun, peneliti hanya menggunakan empat indikator dari Facionne (2018), yaitu interpretasi, analisis, evaluasi, dan inferensi. Pengambilan empat indikator tersebut disesuaikan dengan kebutuhan peneliti. Adapun definisi dari masing-masing indikator Facionne (2018), antara lain: (1) interpretasi (interpretation) yaitu menyatakan kembali dan mengidentifikasi informasi penting pada masalah dengan cara: menginterpretasikan ide, mengodekan, menggolongkan, serta memperjelas maksud masalah yang diberikan; (2) analisis (analysis) yaitu menentukan kaitan atau hubungan antara informasi satu dengan lainnya, konsep, deskripsi, serta penyelesaian dari masalah; (3) evaluasi (evaluation) yaitu kegiatan menilai kredibilitas hasil yang diperoleh atau representasi lain serta menilai kekuatan logis pernyataan; dan (4) inferensi (inference) yaitu mengambil kesimpulan yang logis berdasarkan hasil/bukti yang valid.

Berdasarkan penjelasan di atas, peneliti merumuskan masalah "Bagaimana kemampuan berpikir kritis siswa ketika menyelesaikan masalah matematika pada materi geometri?". Oleh karena itu, tujuan penelitian ini untuk melihat dan menganalisis kemampuan berpikir kritis siswa ketika menyelesaikan masalah matematika pada materi geometri. Selanjutnya, hasil pekerjaan siswa dianalisis sesuai dengan indikator kemampuan berpikir kritis yang ditetapkan peneliti.

\section{METODE}

Penelitian yang dilakukan merupakan penelitian deskriptif-kualitatif. Penelitian ini diikuti oleh 23 siswa kelas X MIPA 2 di SMA Modern Al-Rifa'ie Kabupaten Malang. Instrumen penelitian ini terdiri atas satu masalah geometri sebagai tes berpikir kritis dan wawancara. Masalah geometri yang diberikan adalah konsep mengenai syarat-syarat terbentuknya suatu segitiga. Konsep tersebut adalah jumlah panjang dua sisi segitiga harus lebih besar daripada sisi lainnya.

Peneliti melakukan observasi awal sebagai tahapan awal untuk menemukan masalah yang ada di lapangan. Setelah itu, peneliti menetapkan subjek/siswa untuk diberikan masalah matematika. Hasil pekerjaan siswa kemudian dianalisis berdasarkan empat tahapan berpikir kritis menurut Facione (2018) yaitu interpretasi, analisis, evaluasi, dan inferensi. Hasil tersebut kemudian dinilai dengan menentukan persentase ketercapaian masing-masing indikator. Rumus untuk menentukan persentase ketercapaian, sebagai berikut.

$$
P_{i}=\frac{x_{i}}{n} \times 100 \%
$$


Keterangan:

$P i$ : Persentase ketercapaian indikator ke- $i$

$x_{i}$ : Banyaknya siswa yang memenuhi indikator ke- $i$

$n$ : Banyak siswa keseluruhan

Hasil yang diperoleh kemudian dideskripsikan berupa proses berpikir kritis siswa dalam memecahkan masalah geometri. Untuk mengetahui lebih mendalam terkait proses berfikir, peneliti melakukan wawancara kepada siswa untuk mengungkapkan proses menemukan solusi secara lisan.

\section{HASIL}

Masalah matematika yang diberikan kepada siswa untuk mengukur kemampuan berpikir kritis disajikan sebagai berikut. Dalam rangka memperingati hari ulang tahun sekolah, Betrand dan teman sekelasnya berencana untuk membuat bendera segitiga warna-warni. Setiap bendera harus memiliki ukuran yang sama. Betrand mengusulkan bahwa keliling bendera segitiga tersebut adalah $46 \mathrm{~cm}$. Panjang sisi terpanjang bendera tersebut adalah 3 kali panjang sisi terpendeknya. Sedangkan jumlah dari panjang sisi terpendek dan 3 kali panjang sisi terpanjang adalah $80 \mathrm{~cm}$. Berdasarkan usulan Betrand tersebut, dapatkah mereka menentukan ukuran panjang sisi-sisi segitiga tersebut? Dengan ukuran segitiga tersebut, apakah bendera dapat dibuat? Jelaskan pendapatmu!

Hasil pekerjaan siswa tersebut dianalisis dan dideskripsikan berupa kemampuan berpikir kritis siswa dalam memecahkan masalah matematika pada materi geometri berdasarkan indikator pencapaian yang ditetapkan oleh peneliti. Berikut hasil pekerjaan siswa dari masing-masing indikator kemampuan berpikir kritis.

\section{Interpretasi}

Pada tahapan menginterpretasikan, siswa dapat memahami masalah dengan baik yang ditunjukkan dengan kemampuan siswa dalam menuliskan informasi atau fakta penting pada masalah dalam bentuk kalimat matematika. Dari hasil pekerjaan terdapat 20 siswa dari 23 siswa yang dapat memenuhi indikator intepretasi. Duapuluh siswa ini dapat mengidentifikasikan setiap informasi penting yang dibutuhkan sesuai dengan masalah. Berikut salah satu hasil pekerjaan dari 23 siswa.

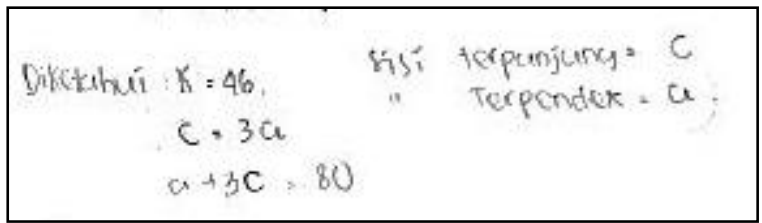

Gambar 3. Pencapaian Siswa pada Tahapan Interpretasi

Pada Gambar 3 terlihat bahwa siswa mampu menuliskan informasi penting yang sesuai dengan masalah. Siswa menuliskan permisalan yaitu $c$ merupakan sisi terpanjang dari segitiga dan $a$ merupakan sisi terpendeknya. Dari permisalan tersebut, siswa menentukan model matematika dengan tepat yaitu $c=3 a$ dan $a+3 c=80$. Selain itu, siswa juga menuliskan informasi penting lainnya yaitu bahwa keliling dari segitiga yang dibuat adalah $46 \mathrm{~cm}$.

Kemampuan siswa dalam memahami masalah memudahkan siswa dalam mengidentifikasi informasi penting yang ada pada masalah. Selain itu siswa mampu merumuskan atau menginterpretasikan masalah tersebut dalam kalimat matematika. Sebaliknya, siswa yang tidak dapat memahami dengan baik masalah yang diberikan mengakibatkan siswa kesulitan dalam menuliskan dan menyatakan kembali permasalahan tersebut. Sesuai dengan hasil penelitian Filah, dkk (2018) bahwa siswa yang mampu memahami masalah dengan baik maka siswa tersebut dapat menentukan fakta atau informasi penting sehingga informasi tersebut dapat digunakan untuk menemukan solusi. Siswa yang telah mampu menyatakan kembali masalah pada soal dan menuliskannya kembali dalam kalimat matematika dapat dikatakan telah mencapai indikator interpretasi. Hasil penelitian Hidayanti, dkk (2016) juga menyatakan bahwa siswa dikatakan mampu melakukan interpretasi dengan baik ketika mereka dapat menyatakan kembali informasi penting dan menuliskan keadaan masalah tersebut dengan tepat. Pencapaian ini penting dimiliki siswa agar memudahkan mereka untuk menyelesaikan masalah. 
Selain dari 23 siswa, terdapat 3 siswa yang masih belum dapat melakukan interpretasi dengan tepat. Hal ini ditunjukkan pada Gambar 4 berikut.

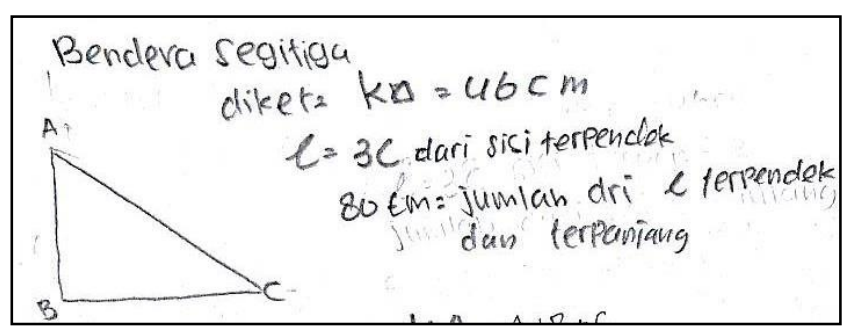

Gambar 4. Pekerjaan Siswa pada Tahapan Interpretasi

Dari Gambar 4 di atas, siswa belum dapat menuliskan informasi masalah dengan tepat. Hal ini terlihat ketika siswa hanya menuliskan " $c=3 c$ dari sisi terpanjang dan $80 \mathrm{~cm}=$ jumlah dari $c$ terpendek dan terpanjang". Siswa tidak dapat mengidentifikasi masalah dengan menentukan permisalan panjang sisi terpanjang dan sisi terpendek. Ketika ditanya siswa juga tidak dapat menjelaskan maksud dari variabel $c$ yang dibuat. Ketidakmampuan siswa dalam memahami masalah tersebut mengakibatkan siswa kesulitan dalam menuliskan model matematika yang tepat. Hal ini diperkuat dengan hasil penelitian Parameswari, dkk (2018) bahwa siswa yang tidak dapat memahami bacaan/masalah yang sedang dihadapinya mengakibatkan kesulitan dalam menentukan model matematika yang merepresentasikan dengan masalah yang ada. Ketidakmampuan siswa dalam memahami masalah tersebut menyebabkan tidak tercapainya indikator interpretasi.

Secara keseluruhan terlihat bahwa terdapat $86,9 \%$ siswa yang mampu melakukan interpretasi dengan baik. Oleh sebab itu, dapat disimpulkan bahwa kemampuan siswa dalam melakukan interpretasi terhadap masalah yang diberikan adalah baik.

\section{Analisis}

Pada tahapan analisis, siswa mampu mengaitkan hubungan antar informasi, menyusun strategi penyelesaian, dan melaksanakan startegi tersebut menggunakan konsep dan prosedur matematika untuk menemukan solusi. Berikut salah satu hasil pekerjaan dari 11 siswa tersebut.

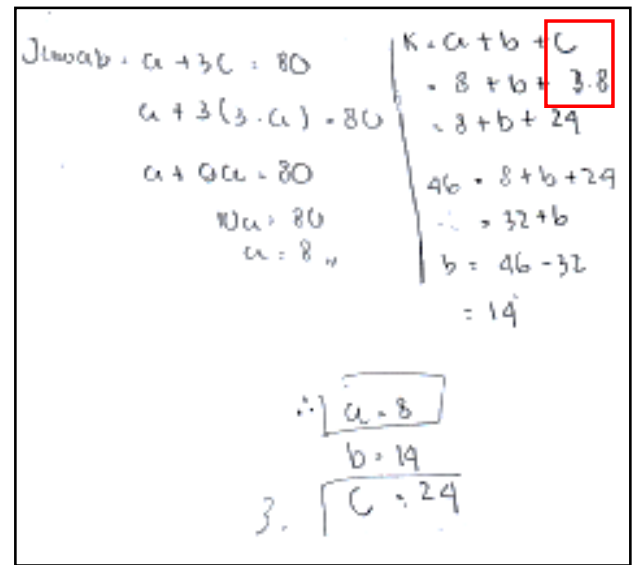

Gambar 5. Pencapaian Siswa pada Tahapan Analisis

Berdasarkan Gambar 5 di atas, langkah awal yang dilakukan siswa adalah dengan mensubstitusikan $c=3 a$ ke dalam persamaan $a+3 c=80$ sedemikian sehingga diperoleh nilai $a=8$. Nilai $a$ ini merupakan panjang sisi terpendek segitiga. Permisalan dan persamaan yang dibuat tersebut merupakan model matematika yang telah dibuat sebelumnya pada Gambar 3. Setelah menentukan nilai $a$, siswa menentukan nilai $b$ yang merupakan sisi kedua segitiga (bukan sisi terpanjang dan sisi terpendek) dengan menggunakan konsep keliling segitiga. Karena keliling segitiga tersebut adalah $46 \mathrm{~cm}$ maka $\mathrm{K}=a+b+c=46$. Untuk menyelesaikan persamaan tersebut, siswa mensubstitusikan nilai $a=8$ dan nilai $c=3 a=3(8)=24$ ke dalam persamaan $a+b+c=46$. Nilai $c=24$ tersebut dapat dilihat pada kotak merah di Gambar 5. Setelah menyelesaikan persamaan dengan prosedur matematika yang benar maka diperoleh nilai $b=14$. Siswa dapat menentukan ukuran 
sisi-sisi pada segitiga tersebut dengan benar yaitu $a=8 \mathrm{~cm}$ (sisi terpendek), $b=14 \mathrm{~cm}$ (sisi kedua), dan $c=24 \mathrm{~cm}$ (sisi terpanjang).

Dari pekerjaan siswa terlihat bahwa siswa dapat menjalankan strategi penyelesaian dengan runtun. Siswa juga dapat menghubungkan antar informasi dengan penerapan konsep yang baik serta prosedur pelaksanaan yang tepat. Oleh sebab itu, siswa telah mencapai indikator analisis. Seperti tulisan Facione (2018) bahwa tahapan analisis dicapai ketika siswa telah mampu melihat hubungan dan mengaitkan informasi satu dengan lainnya, mengidentifikasi pertanyaan masalah yang kemudian untuk menyusun strategi penyelesaian, serta menerapkan konsep dalam menemukan penyelesaian masalah. Selain itu, pemahaman konsep yang kuat sebagai salah satu syarat agar dapat menggunakan kemampuan berpikir kritis dengan optimal. Dengan pemahamn konsep yang baik maka seseorang dapat memiliki ide serta memahami sesuatu secara jelas sehingga proses penyelesaian masalah dapat berjalan dengan baik (Rahman, 2019).

Pada tahapan analisis ini juga terdapat 12 siswa lainnya yang belum mencapai indikator analisis. Keduabelas ini dapat menyelesaikan masalah yang diberikan dengan konsep segitiga namun masih terdapat perhitungan yang salah dan persepsi yang salah pada siswa. Sehingga ketika ditanya oleh peneliti, siswa masih bingung untuk menentukan ukuran segitiga tersebut. Berikut salah satu hasil pekerjaan dari 12 siswa.

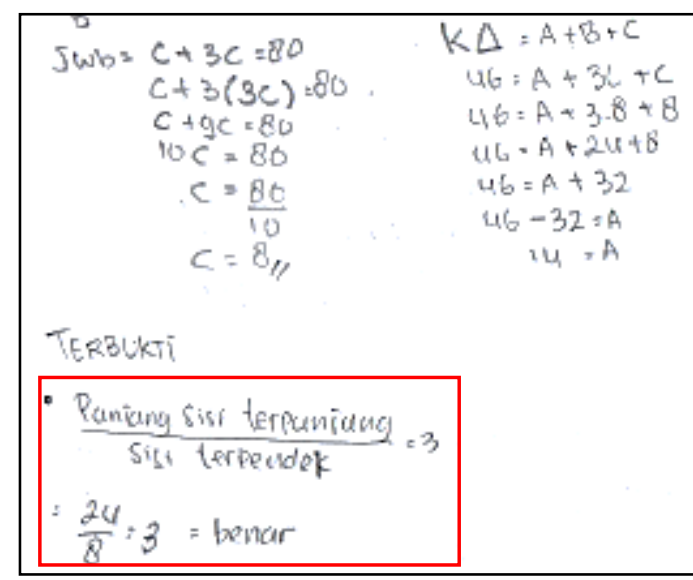

Gambar 6. Pekerjaan Siswa pada Tahapan Analisis

Dari Gambar 6 di atas, siswa menuliskan persamaan " $c+3 c=80$ ". Persamaan ini diperoleh dari tahapan interpretasi siswa pada Gambar 4 sebelumnya. Jika diteliti lebih lanjut, persamaan yang dibuat siswa tersebut salah, seharusnya jika siswa memisalkan $c$ sebagai sisi terpendek segitiga dan ada variabel $b$ sebagai sisi terpanjang maka model matematika yang tepat adalah $c+3 b=80$. Walaupun hasil yang diperoleh siswa tersebut benar namun terdapat konsep-konsep yang masih salah dan pemahaman siswa terhadap masalah masih kurang. Hal ini diketahui ketika siswa diwawancarai, siswa kebingungan dan mengaku bahwa siswa hanya melihat jawaban temannya. Siswa tidak dapat menjelaskan nilai $\mathrm{A}=14$ tersebut dengan benar. Siswa hanya menjelaskan bahwa nilai A itu adalah sisi segitiga. Tetapi siswa tidak dapat menentukan apakah A tersebut merupakan sisi terpanjang atau sisi terpendek atau bukan keduanya. Jika dilihat pada kotak merah Gambar 4 tersebut, siswa dapat menuliskan dengan jelas perbandingan antara sisi terpanjang dan sisi terpendek yaitu $\frac{24}{8}=3$. Dengan kata lain, sisi terpanjang segitiga tersebut adalah $24 \mathrm{~cm}$ dan sisi terpendeknya adalah $8 \mathrm{~cm}$. Namun siswa tidak dapat menjelaskan maksud dari tulisan tersebut. Ketidakmampuan siswa dalam memehami masalah dengan baik berakibat pada kesulitan siswa untuk memberikan kesimpulan jawaban yang diperoleh.

Secara keseluruhan, dapat disimpulkan bahwa kemampuan siswa dalam melakukan analisis masih kurang. Hal tersebut terlihat dari hasil pekerjaan siswa yang hanya mencapai $47,8 \%$ siswa yang memenuhi indikator analisis. 


\section{Evaluasi dan Inferensi}

Pada tahapan evaluasi, siswa harus mampu menilai atas kredibilitas informasi atau pernyataan dari hasil penyelesaian masalah. Tahapan ini dianggap sulit tercapai dikarenakan tidak ada satupun siswa yang mampu menentukan apakah masalah yang diberikan memiliki penyelesaian yang logis. Siswa hanya menduga dan memberikan alasan tanpa memperhatikan teorema yang berlaku pada segitiga. Sedangkan tahapan inferensi ini merupakan tahapan dimana siswa mampu menarik kesimpulan terhadap jawaban yang diperoleh berdasarkan pernyataan-pernyataan yang logis. Oleh karena tidak ada siswa yang mampu mencapai tahapan evaluasi maka siswa juga tidak dapat melakukan inferensi. Penelitian yang dilakukan Hidayanti, dkk (2016) juga demikian bahwa tahapan inferensi tidak dapat tercapai dikarenakan siswa tidak dapat melakukan evaluasi dengan baik. Berikut salah satu hasil pekerjaan siswa.

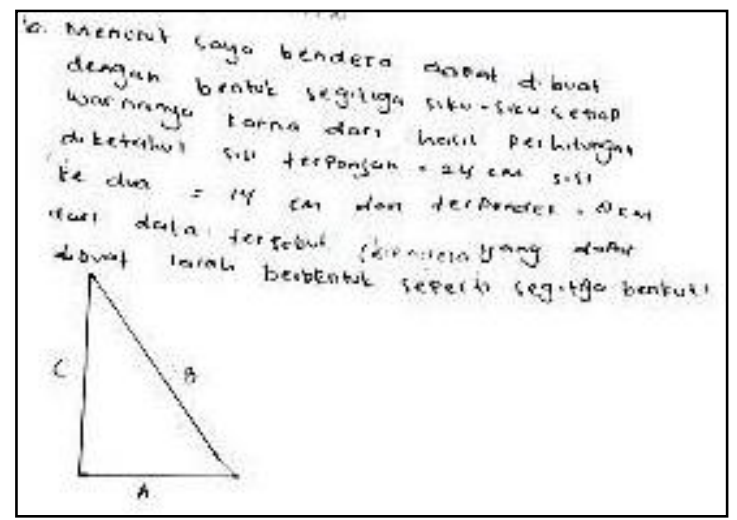

Gambar 7. Pekerjaan Siswa pada Tahapan Evaluasi dan Inferensi

Berdasarkan Gambar 7 terlihat bahwa siswa langsung menentukan bahwa dari hasil perhitungan yang diperoleh yaitu sisi terpanjang segitiga $24 \mathrm{~cm}$, sisi keduanya adalah $14 \mathrm{~cm}$, dan sisi terpendek segitiga adalah $8 \mathrm{~cm}$ maka bendera (berbentuk segitiga) dapat dibuat. Semua siswa beranggapan bahwa karena ketiga sisi segitiga dapat diketahui panjangnya maka terbentuk suatu segitiga. Siswa juga salah dalam membuat keputusan dimana siswa menganggap bahwa segitiga tersebut adalah segitiga siku-siku tanpa memperhatikan konsep Pythagoras yang berlaku pada segitiga siku-siku. Sebagian siswa juga menjawab bahwa segitiga yang terbentuk adalah segitiga sebarang dengan alasan bahwa ketiga sisinya memiliki panjang yang berbeda. Tentu saja semua jawaban siswa tersebut salah.

Jika diperhatikan dan mengingat teorema ketidaksamaan segitiga dinyatakan bahwa syarat terbentuknya segitiga adalah jumlah dari kedua sisi pada segitiga selalu lebih panjang dari sisi ketiganya. Misalkan dalam masalah ini sisi terpanjang $(a)=24 \mathrm{~cm}$, sisi kedua $(\mathrm{b})=14 \mathrm{~cm}$, dan sisi terpendek $(\mathrm{c})=8 \mathrm{~cm}$ maka untuk menentukan apakah bendera/segitiga dapat terbentuk dapat menggunakan teorema ketidaksamaan segitiga, yaitu $b+c=14+8=22<24=a$. Karena jumlah kedua sisi segitiga tersebut lebih pendek dari sisi ketiganya maka segitiga tidak dapat terbentuk.

Secara keseluruhan pada tahapan evaluasi ini siswa tidak dapat membuktikan dengan benar bahwa ketiga sisi segitiga tersebut tidak dapat membentuk segitiga. Hal ini yang menyebabkan siswa tidak dapat mencapai indikator evaluasi. Sejalan dengan hasil penelitian Basri, dkk (2019) siswa yang tidak memiliki kemampuan mengevaluasi ini menyebabkan siswa kesulitan dalam memberikan pernyataan dan pembuktian matematika dengan benar.

Berdasarkan hasil pekerjaan siswa pada Gambar 7 terlihat bahwa siswa memberikan kesimpulan yang salah. Tentu saja ini berkaitan dengan pengambilan keputusan yang tidak berdasarkan penjelasan atau pernyataan yang logis. Jika dikaitkan dengan teorema ketidaksamaan segitiga maka pada masalah matematika tersebut tidak dapat diselesaikan dikarenakan segitiga yang dimaksud oleh Betrand adalah tidak ada. Ketidakmampuan siswa dalam menarik kesimpulan yang tepat berdasarkan argument yang valid maka siswa tidak dapat melakukan inferensi dengan baik. Sesuai dengan pendapat Ficone (2018) bahwa siswa yang dapat melakukan inferensi ini ialah siswa 
yang mampu memberikan kesimpulan yang logis (masuk akal) berdasarkan pernyataan yang benar pula.

Proses evaluasi dan inferensi ini merupakan salah satu bagian yang terpenting untuk memiliki kemampuan berpikir kritis. Oleh karena sebagian besar siswa hanya mampu mencapai pada tahapan interpretasi dan analisis maka kemampuan berpikir kritis siswa masih tergolong rendah.

\section{SIMPULAN DAN SARAN}

Hasil penelitian dan pembahasan menunjukkan bahwa kemampuan berpikir kritis siswa masih tergolong rendah. Hal ini terlihat pada pencapaian indikator kemampuan berpikir kritis yang tidak optimal. Indikator untuk mengukur kemampuan berpikir kritis terdiri atas: Interpretasi, analisis, evaluasi, dan inferensi. Siswa yang mampu melakukan interpretasi dalam menyelesaikan masalah sebanyak 20 siswa dari 23 siswa atau 86,9\%. Pada tahapan interpretasi, sebagian besar siswa mampu menggambarkan dan menyatakan kembali masalah sehingga siswa dapat menuliskan informasi penting yang digunakan dalam kalimat matematika. Pada tahapan analisis hanya dicapai 11 siswa atau $47,8 \%$. Kemampuan siswa dalam menganalisis masalah masih kurang terlihat dari ketidakmampuan siswa dalam menghubungkan informasi dengan penerapan konsep segitiga sehingga hasil penyelesaian masalah tidak tepat. Hal ini juga yang menyebabkan tidak ada satupun siswa yang mampu mencapai indikator evaluasi dan inferensi. Siswa masih kesulitan dalam mengambil keputusan yang tepat berdasarkan perhitungan dan pernyataan yang valid.

Lemahnya kemampuan berpikir kritis siswa dalam menyelesaikan masalah matematika perlu menjadi perhatian khusus. Untuk dapat menghadapi perkembangan zaman di abad ke-21 ini siswa dituntut untuk dapat memiliki kemampuan berpikir kritis. Oleh sebab itu, penting bagi tenaga pendidik dan peneliti untuk dapat memberikan pembelajaran yang inovatif dan latihan soal matematika yang menuntut siswa berpikir kritis. Dengan demikian siswa akan terbiasa dan dapat memecahkan masalah matematika dengan baik. Selain itu, untuk mengukur kemampuan berpikir kritis siswa dapat dilakukan dengan proses wawancara. Disarankan kepada peneliti lainnya agar dapat melakukan wawancara secara mendalam sehingga diperoleh hasil yang detail dan akurat terkait proses berpikir siswa.

\section{DAFTAR RUJUKAN}

As'ari, A, R. (2016). Tantangan Pengembangan Profesionalisme Guru dalam Rangka Membelajarkan Matematika di Abad ke-21 dan Membangun Karakter Peserta Didik. Dipublikasikan di https://www.researchgate.net/publication/311067194.

As'ari, A, R., Mahmudi, A., \& Nuerlaelah., E. (2017). Our Prospective Mathematic Teachers Are Not Critical Thinkers Yet. Journal on Mathematics Education, 8(2): 145-156.

Basri, H., Purwanto, As'ari, A. R., \& Sisworo. (2019). Investigating Critical Thinking Skill of Junior High School in Solving Mathematical Problem. International Journal of Instruction, 12(3): 745-758.

Cahyono, B. (2017). Analisis Ketrampilan Berpikir Kritis Dalam Memecahkan Masalah Ditinjau Perbedaan Gender. Aksioma, 8(1): 50-64.

Chukwuyenum, A. N. (2013). Impact of Critical Thinkingon Performance in Mathematics among Senior Secondary School Students in Lagos State. IOSR Journal of Reasearch \& Method in Education (IOSR$J R M E, 3(5): 18-25$.

Duron, R., Limbach, B., \& Waugh, W. (2006). Critical Framework for Any Dicipline. International Journal of Teaching and Learning in Higher Education, (online), 17(2): 160-166.

Ennis, R. (1985). Curriculum for Critical Thinking Developing Minds: A Resource Book For Teaching Thinking. Alexandria: Association for Supervision and Curriculum Development.

Ennis, R. H. (2011). The Nature of Critical thinking: An Outline of Critical Thinking Dispositions and Abilities. Illinois: University of Illinios, (online), (https://www.google.com/url?sa=t\&rct=j\&q=\&esrc=s\&source= web\&cd=1\&cad=rja\&uact=8\&ved=0ahUKEwj6uZaYheTSAhVBrI8KHcagCOMQFggbMAA\&url=http $\% 3 \mathrm{~A} \% 2 \mathrm{~F} \% 2 \mathrm{Ffaculty}$.education.illinois.edu\%2Frhennis\%2Fdocuments\%2FTheNatureofCriticalThinking _51711_000.pdf\&usg=AFQjCNHAs1qGj67PwzGZuFM6ygKJg_A9w\&sig2=VjpSW2GG102bFQdPqU V3_w\&bvm=bv.149760088,d.c2I), diakses tanggal 10 November 2019. 
Facione, P. A. (2018). Critical thinking: What it Is and Why It Counts. Hermosa Beach: Insight Assessment, (online), (https://www.insightassessment.com/content/download/1176/7580/file/what\&why.pdf), diakses tanggal 15 November 2019.

Felder, R. M., \& Brent, R. (2016). Teaching and Learning STEM A Pratical Guide. USA: Jossey-Bass A wiley Brand.

Filah, A., N., Dafik, \& Kusno. (2018). The Analysis of Students' Critical Thinking Skills in Solving the Generalization Problem of Mathematics Series. The International Journal of Social Sciences and Humanities Invention, 5(1): 4314-4321.

Firdaus, Kailani, I., Bakar, M., N., B., \& Bakry. (2015). Developing Critical Thinking Skills of Students in Mathematics Learning. Journal of Education and Learning, 9(3): 226-236.

Hidayanti, D., As'ari, A. R., \& Chandra, T. D. (2016). Analisis Kemampuan Berpikir Kritis Siswa SMP Kelas IX Pada Materi Kesebangunan. Konferensi Nasional Penelitian Matematika dan Pembelajarannya (KNPMP I)(Prosiding): 276-285.

Kemdikbud. (2016). Peraturan Menteri Pendidikan dan Kebudayaan Republik Indonesia Nomor 20 Tahun 2016 Tentang Standar Proses Pendidikan Dasar dan Menengah. Jakarta: Kemdikbud.

Parameswari, P., Chandra, T. D., \& Susiswo. (2018). Pelaksanaan Scaffolding untuk Mengatasi Kesulitan Siswa dalam Menyelesaikan Masalah PtLSV. Jurnal Pendidikan: Teori, Penelitian, \& Pengembangan, 3(5): 656-670.

Rahman, M., M. (2019). 21 ${ }^{\text {st }}$ Century Skill "Problem Solving”: Defining the Concept. Asian Journal of Interdisciplinary Research, 2(1): 71-81.

Syarifah, T. J., Usodo, B., \& Riyadi. (2018). Higher Order Thinking (HOT) Problems To Develop Critical Thinking Ability And Student Self Efficacy in Learning Mathematics Primary Schools. SHEs: Conference Series, 1(1): 917-925.

Widana, I. wayan, Adi, S., Herdiyanto, Abdi, J., Marsito, \& Istiqomah. (2019). Modul Penyusunan Soal HOTS. Kementrian Pendidikan dan Kebudayaan: Jakarta. 